\title{
Effectiveness of Condroprotectors in Treating Osteoarthritis: a Bibliographic Review
}

\author{
Alana Gomes de Souza ${ }^{1 *}$, Malu Avila Sobrinho de Vasconcelos ${ }^{2}$, Nathalia Moura Fernandes ${ }^{2}$, \\ Cintia Justino Rabelo ${ }^{3}$, Bruno Souza dos Santos ${ }^{4}$, Marta Maria de França Fonteles ${ }^{1}$ \\ ${ }^{1}$ Universidade Federal do Ceará; ${ }^{2}$ Centro Universitário Farias de Brito; ${ }^{3}$ Centro Universitário Católica \\ de Quixadá; ${ }^{4}$ Universidade Federal de Pernambuco;
}

\section{ABSTRACT}

Introduction: Osteoarthritis (OA) is the most common rheumatologic disease in the world and the elderly are the most affected, although there is no defined age for its onset. Obesity is a risk factor, with healthy eating habits and physical exercise practices being recommended for treatment and prevention. The pharmacological treatment for $\mathrm{OA}$ is oral chondroprotective agents and viscosupplements, although anti-inflammatory drugs are widely prescribed, they do not cause clinical improvement, they only treat the symptoms of the disease. Objective: This study gathered articles from clinical trials in Brazil with the purpose of investigating whether the pharmacological treatments used are effective. Methods: The electronic platforms used for data collection were: Scielo, CAPES Journal Portal and Google Academic. Articles published in the last six years with clinical trials in Brazil were considered. Articles involving surgeries, those that used physiotherapy as an adjunct therapy and those that used animal or non-human research in their research were excluded. The search was through the descriptors: hyaluronic acid, glucosamine and chondroitin. Results: The search resulted in six articles, in which three were used chondroprotectors and the other three viscosupplements. Chondroprotectors were effective in $66.66 \%$ of clinical trials and viscosupplements in $100 \%$. Conclusion: Pharmacological treatments for OA showed high efficacy, however the sample of the present work was small, thus, further studies are needed to confirm the results obtained.

Keywords: Osteoarthritis. Chondroprotectors. Viscosupplement.
*Correspondence to Author:

Alana Gomes de Souza

Universidade Federal do Ceará

How to cite this article:

Alana Gomes de Souza, Malu Avila Sobrinho de Vasconcelos, Nathalia Moura Fernandes, Cintia Justino Rabelo, Bruno Souza dos Santos, Marta Maria de França Fonteles. Effectiveness of Condroprotectors in Treating Osteoarthritis: a Bibliographic Review.American Journal of Orthopedic Research and Reviews, 2021, 4:25

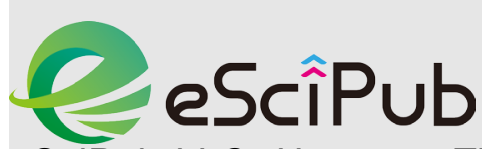
eSciPub LLC, Houston, TX USA. Website: https://escipub.com/ 


\section{INTRODUCTION}

Osteoarthritis $(\mathrm{OA})$ is the main rheumatic disease, which affects the joints in a degenerative way, representing 30 to $40 \%$ of the pathologies in rheumatological consultations. Although the Brazilian Society of Rheumatology does not have statistical data on how many Brazilians suffer from OA, it is known that it is more frequent above the age of 50 and in women [10].

$\mathrm{OA}$ is a chronic disease with difficult clinical improvement, but there is control to prevent its evolution, such as healthy eating and physical exercise practices in the treatment, which significantly improve its progression ${ }^{[13]}$.

Obesity is a comorbidity that aggravates the evolution of the disease, since the weight on the cartilage does not favor physical improvements. This is considered by Sartori-Cintra, Aikawa and Cintra (2014) ${ }^{[16]}$, the greatest risk factor for the development of $O A$, also associated with other diseases such as diabetes mellitus, hypertension and dyslipidemia ${ }^{[16]}$.

In addition to a healthy and balanced diet aimed at weight loss and exercise being fundamental in the treatment of $O A$, the use of oral chondroprotective drugs and viscosupplements in the treatment is also a clinical option, being even more effective when they are associated [12].

Pharmacological treatments for $\mathrm{OA}$ in the management of pain and inflammation of the cartilage affected by wear involve several pharmacological classes: analgesics, nonsteroidal anti-inflammatory drugs, corticosteroids and opioids. Chondroprotectors and viscosupplements act by returning the cartilaginous matrix, preventing or delaying the evolution of rheumatic disease ${ }^{[7]}$.

Chondroprotectors are safe drugs for the treatment of $\mathrm{OA}$ and considerably decrease the use of non-steroidal anti-inflammatory drugs, promising to repair the cartilage damage suffered, reducing pain and physical injury [12].
These agents stimulate the production of the cartilaginous matrix, but to observe the effect, it is necessary to use the medication for a few weeks, since it does not produce an immediate analgesic effect. On the other hand, even after suspension, the pharmacological effect remains for a few weeks ${ }^{[7]}$.

The main viscosupplement used is hyalaluronic acid, which is already present in joints with a fluidizing effect. As people with OA have a reduced amount of hyalaluronic acid, viscosupplements are, in most cases, injected directly into the joint to prevent friction caused by their natural loss, thereby relieving the pain caused by its loss ${ }^{[2]}$.

The main complaint of patients with OA, like any other rheumatic disease, is pain. This is the main cause of the abundance of prescriptions for antiinflammatory drugs and opioids, since chronic pain considerably affects the quality of life of patients [5]. Pain is also the main clinical manifestation for diagnosis [10].

Pain harms health not only physically, there is physical exhaustion that affects the patient psychologically, leading in many cases to mental disorders. Of the psychological diseases in women with knee OA, the most observable are anxiety and depression ${ }^{[6]}$.

$O A$ is the main type of rheumatic disease in the world ${ }^{[10]}$. Due to the need to gather studies that show the efficacy of drug therapy with viscosupplements and chondroprotectors for $\mathrm{OA}$, this bibliographic study gathered data that show results of work performed. Thus, the objective of the present study is to evaluate studies already published of patients with OA who are treated with medications to treat the disease and its progression.

\section{METHODS}

This is a literature review of the drugs used to treat $\mathrm{OA}$, considering those that treat the disease and its progression, namely hyaluronic acid, chondroitin and glucosamine. Articles that treat isolated pain and inflammation with 
steroidal, non-steroidal and opioid antiinflammatory drugs were disregarded.

The research was carried out by means of data collection on the electronic platforms Scielo, "Portal de Periódicos da Capes", Google scholar and BVS. The keywords used in the electronic platforms in the research were: osteoarthritis, pharmacological treatment, viscosupplements, chondroprotectors.

For this study, articles published in the last 6 years with clinical trials in Brazil with prevalence on age, sex, number of patients in each research and considering the effective or non-effective treatment were considered. Effective if there was clinical improvement of the patient or if considered effective by the published study and not effective if there was no clinical improvement.

This research did not include articles that had physiotherapy as adjuvant therapy, studies that had associated surgeries in order to intervene in this disease, and that used animal or non-human trials as models.

The search in the databases cited occurred between February and June 2019. Considering the criteria mentioned above, six articles were found for this review, taken from the electronic platforms.

\section{RESULTS AND DISCUSSION}

Six articles were found in the cited databases that fit the inclusion and exclusion criteria of this work (Table 1). Scielo was the first platform used, with the largest number of articles presented here being found. Articles were found on the Google academic platform, some duplicated with the first search. In the Portal of Periodicals at Capes, all those found had already been mentioned by the previous platforms.

\section{Table 1: Descriptions of the articles found}

\begin{tabular}{|c|c|c|c|c|c|}
\hline Paper & $\begin{array}{l}\text { Number of } \\
\text { patients }\end{array}$ & $\begin{array}{l}\text { Gender } \\
\text { prevalence }\end{array}$ & Age & Treatment & Result \\
\hline SALVATO, Katia F. et al & 91 & Female & $>59$ & $\begin{array}{l}\text { Chondroitin } \\
\text { Glycosamine }\end{array}$ & Effective \\
\hline $\begin{array}{l}\text { SANTOS, João Paulo 'M. } \\
\text { et al. }\end{array}$ & 105 & Female & $>59$ & $\begin{array}{l}\text { Chondroitin } \\
\text { Glycosamine }\end{array}$ & Not effective \\
\hline $\begin{array}{l}\text { NAHAS, Ricardo Munir et } \\
\text { al }\end{array}$ & 24 & Not available & $>31$ & Viscosupplement & Effective \\
\hline BONOTTO, Daniel et al & 55 & Female & $>16$ & Viscosupplement & Effective \\
\hline $\begin{array}{l}\text { ZOBOLI, Alejandro } \\
\text { Agustin Carri et al }\end{array}$ & 108 & Not available & $\begin{array}{l}\text { Not } \\
\text { available }\end{array}$ & Viscosupplement & Effective \\
\hline $\begin{array}{l}\text { ALVES, Janice } \\
\text { BASSITT, Debora P. }\end{array}$ & 20 & Female & $>59$ & $\begin{array}{l}\text { Chondroitin } \\
\text { Glycosamine }\end{array}$ & Effective \\
\hline
\end{tabular}

It was observed that $83.33 \%$ of the selected articles had as main objective to test the effectiveness of the drugs used for $\mathrm{OA}$, while only $16.67 \%$ did not have this central objective. Studies involving chondroprotectors combined glucosamine and chondroitin. Viscosupplement treatments involved hyaluronic acid injected into the joint affected by OA.

Of the six selected works, three addressed chondroprotectors, and the other three viscosupplements. In the studies related to chondroitin and glucosamine, in general, 216 patients were involved, $51.38 \%$ of which were considered effective and safe as treatment for OA. Representing $66.66 \%$ of the articles presented.

In the study by Salvato et al. (2015) ${ }^{[14]}$, there is a comparison about the impact on the lives of people who treat OA with chondroprotectants and anti-inflammatory drugs, with more mental than physical damage, especially in relation to anti-inflammatory drugs. Revealing that the 
chondroprotectors glucosamine and chondroitin present better clinical efficacy, blocking alterations with strong potential in the viscoelastic characteristics of the cartilage.

Santos et al. (2015) ${ }^{[15]}$ considered low functional capacity in the patients monitored in their study. There is no improvement in pain, stiffness and physical function. Considering the association of glucosamine and chondroitin ineffective, emphasizing that OA has a multifactorial cause and that these drugs do not modulate important cytokines of this pathology (IL1- $\beta$, TNF- $\alpha$ and IL6 ) produced by synovial tissues, osteoblasts and chondrocytes.

Alves and Bassitt (2013) ${ }^{[1]}$ chose to consider only women in their study and the age above 60 years, as most national works carried out on OA. Of the total of 40 participants, $50 \%$ used glucosamine and chondroitin, which were considered effective and safe drugs, since the participants declared that they did not affect the quality of life in general.

Viscosupplements represent $50 \%$ of the results found. In all studies, considering 187 patients, they remained effective in $100 \%$ of the results.

Nahas et al. (2016) [11] analyzed viscosupplements for treatment of knee OA after trauma to the tibial plateau over a 12-month period. There was a significant improvement in pain after the first months of the start of its infusion. Considering effective treatment and a good therapeutic option for the long term.

In the study by Bonotto et al. (2014) ${ }^{[3]}$, there was the application of viscosupplements in the temporomandibular joint. Patients had difficulty opening the mouthpiece, and treatment with hyaluronic acid proved to be effective, allowing an increase in the mouthpiece opening.

In the article by Zóboli et al. (2013) ${ }^{[17]}$, a clinical trial of applying viscosupplements in a single and weekly regime was elaborated. It was found that the application of $2 \mathrm{ml}$ three times a week gives greater mobility and less pain, considering it effective.
In all the studies used, the female gender remained prominent. Of the total of 403 patients, $230(57.07 \%)$ were over 60 years of age and $42.93 \%$ were under 59 years old or did not have the disclosed age.

According to a study by Campos (2014) [4], chondroprotectors are effective and safe drugs, and for him, other studies and entities that adhere to the disuse of chondroprotectors are totally dogmatic, despite the pharmacology not very clear.

However, the research by Lopes Junior and Inacio (2013) ${ }^{[9]}$, mentions that glucosamine and chondroitin are, due to the lack of evidence in studies in patients with $O A$, clinically irrelevant and that their clinical prescription is unnecessary to treat knee and hip OA.

\section{FINAL CONSIDERATIONS}

The present study showed that OA is a disease that is present in a large part of the Brazilian population and in the world, however, it is still little investigated. Oral chondroprotectors and viscosupplements are the main drugs used in the treatment of $O A$ and the results presented showed that chondroprotectors had an efficacy of $66.66 \%$ of the articles presented and viscosupplements $100 \%$ effective.

However, the number of the sample used was very small and the articles presented represent a minority, since only studies carried out in Brazil were used, which is a limitation of the present study. Thus, further studies are needed to fully elucidate the efficacy of pharmacological treatment for OA.

\section{REFERENCES}

[1]. ALVES, Janice Chaim; BASSITT, Debora Pastore. Qualidade de vida e capacidade funcional de idosas com osteoartrite de joelho. Einstein (São Paulo), 2013, 11.2: 209-215.

[2]. AMMAR, Tiago Youssef, et al. Viscossuplementacão no tratamento da osteoartrose do joelho: uma revisão da literatura. Revista Brasileira de Ortopedia, 2015, 50.5: 489494.

[3]. BONOTTO, Daniel, et al. Viscosupplementation as a treatment of internal derangements of the 
Alana Gomes de Souza et al., AJORR, 2021, 4:25

temporomandibular joint: retrospective study. Revista Dor, 2014, 15.1: 2-5.

[4]. CAMPOS, Gustavo Constantino de. Chondroprotective agents: are we being too dogmatic?. MedicalExpress, 2014, 1.4: 211-213.

[5]. CARVALHO, Ravena Carolina de, et al. Prevalence and characteristics of chronic pain in Brazil: a national internet-based survey study. BrJP, 2018, 1.4: 331-338.

[6]. FERREIRA, Alyne Hevellen, et al. Investigação da ansiedade, depressão e qualidade de vida em pacientes portadores de osteoartrite no joelho: um estudo comparativo. Revista Brasileira de Reumatologia, 2015, 55.5: 434-438.

[7]. JOSÉ, Fábio Freire. Osteoartrite: fisiopatologia e tratamento medicamentoso. J. Bras. Med., 2013, 101.02: 47-52, 2013.

[8]. LAIRES, Pedro A., et al. Inadequate pain relief among patients with primary knee osteoarthritis. Revista brasileira de reumatologia, 2017, 57.3: 229-237.

[9]. LOPES JUNIOR, Osmar Valadao; INACIO, Andre Manoel. Uso de glucosamina e condroitina no tratamento da osteoartrose: uma revisão da literatura. Revista Brasileira de Ortopedia, 2013, 48.4: 300-306.

[10]. MARIANO, R.N. Comissão de Osteoartrite da sociedade Brasileira de Reumatologia. 2011. Available

$<$ https://www.reumatologia.org.br/doencas-

reumaticas/osteoartrite-artrose/> Access in Feb 21, 2019.

[11]. NAHAS, Ricardo Munir, et al. Viscossuplementação no tratamento de artrite pós-traumática de joelho durante 12 meses. Revista Brasileira de Medicina do Esporte, 2016, 22.6: 465-470.

[12]. REZENDE, Márcia Uchôa; DE CAMPOS, Gustavo Constantino; PAILO, Alexandre Felício. Conceitos atuais em osteoartrite. Acta Ortopédica Brasileira, 2013, 21.2: 120-122.

[13]. ROSIS, R. G.; MASSABKI, Paulo Sérgio; KAIRALLA, Maisa. Osteoartrite: avaliação clínica e epidemiológica de pacientes idosos em instituição de longa permanência. Rev Bras Clin Med, 2010, 8.2: 101-8.

[14]. SALVATO, Katia F., et al. Análise da influência da farmacoterapia sobre a qualidade de vida em idosos com osteoartrite. Revista Brasileira de Reumatologia, 2015, 55.1: 83-88.

[15]. SANTOS, João Paulo M., et al. Análise da funcionalidade de idosos com osteoartrite. Fisioterapia e Pesquisa, 2015, 22.2: 161-168.
Priscila; CINTRA, Dennys Esper Correa. Obesidade versus osteoartrite: muito além da sobrecarga mecânica. Einstein (São Paulo), 2014, 12.3: 374-379.

[17]. ZÓBOLI, Alejandro Agustin Carri, et al. Ensaio clínico prospectivo e randomizado: regime único e semanal de viscossuplementação. Acta Ortopédica Brasileira, 2013, 21.5: 271-275.

[16]. SARTORI-CINTRA, Angélica Rossi; AIKAWA, 